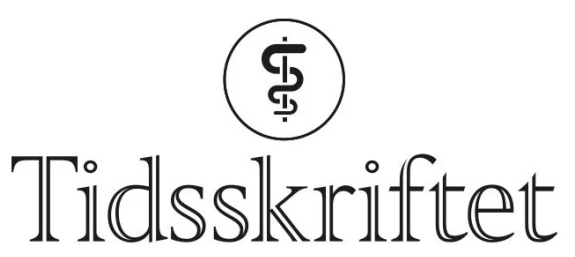

DEN NORSKE LEGEFORENING

\title{
Puberteten starter tidligere
}

DEBATT

INGVILD SAEROLD BRUSERUD

ingvild.bruserud@uib.no

Ingvild Særvold Bruserud er ph.d., postdok og sykepleier ved Barne- og ungdomsklinikken på Haukeland universitetssjukehus.

Forfatter har fylt ut ICMJE-skjemaet og oppgir ingen interessekonflikter.

\section{NINNIE HELÉN BAKKEN OEHME}

Ninnie Helén Bakken Oehme er ph.d. og lege i spesialisering i pediatri ved Barne- og ungdomsklinikken på Haukeland universitetssjukehus.

Forfatter har fylt ut ICMJE-skjemaet og oppgir ingen interessekonflikter.

\section{ANDRÉ MADSEN}

André Madsen er molekylærbiolog, ph.d. og postdoktor ved Hormonlaboratoriet, Avdeling for medisinsk biokjemi og farmakologi ved Helse Bergen.

Forfatter har fylt ut ICMJE-skjemaet og oppgir ingen interessekonflikter.

\section{KAREN ROSENDAHL}

Karen Rosendahl er spesialist i radiologi, overlege ved Barne- og ungdomsseksjonen, Radiologisk avdeling ved Universitetssykehuset i Nord-Norge og professor ved Universitetet i Troms $\emptyset$. Forfatter har fylt ut ICMJE-skjemaet og oppgir ingen interessekonflikter.

\section{ROBERT BJERKNES}

Robert Bjerknes er spesialist i pediatri og overlege ved Barne- og ungdomsklinikken ved Haukeland universitetssykehus. Han er professor og viserektor ved Universitetet i Bergen.

Forfatter har fylt ut ICMJE-skjemaet og oppgir ingen interessekonflikter.

\section{MATHIEU ROELANTS}

Mathieu Roelants er er biostatistiker, ph.d. og postdok ved Department of Public Health and Primary Care, University of Leuven, Belgia.

Forfatter har fylt ut ICMJE-skjemaet og oppgir ingen interessekonflikter.

\section{PÉTUR B. JÚLÍUSSON}

Pétur B. Júlíusson er spesialist i pediatri, overlege ved Barne- og ungdomsklinikken, Haukeland universitetssjukehus, avdelingsdirektør ved Avdeling for helseregisterforskning og -utvikling, Folkehelseinstituttet, og professor ved Universitetet i Bergen.

Forfatter har fylt ut ICMJE-skjemaet og oppgir ingen interessekonflikter. 


\section{Nye norske data viser at medianalder for starten av puberteten hos norske jenter er seks måneder lavere enn tidligere antatt.}

Nye vekstkurver for norske jenter og gutter ble publisert i 2009 (1). På dette tidspunktet forelå det ikke data for pubertetsutvikling hos norske barn og unge. Pubertetsreferanser fra Danmark innsamlet i perioden 1991-1993 ble derfor inkludert i de norske vekstkurvene for aldergruppen 4-19 år (2). Både danske og andre internasjonale studier har senere vist at pubertetsstarten forskyves mot lavere aldre, fortrinnsvis hos jenter (3). Nå er kunnskap om pubertetsutviklingen hos norske barn tilgjengelig, basert på data fra Vekststudien i Bergen $2(4,5)$. Vi har derfor revidert vekstkurvene fra 2009 ved å legge inn disse referansene for normal pubertet hos jenter og gutter.

\section{Hvordan bruke pubertetsreferansen}

En evaluering av pubertetsutvikling baserer seg først og fremst på en klinisk undersøkelse av sekundære kjønnskarakteristika. Hos jenter defineres pubertetsstart av om brystutviklingen har begynt. Hos gutter defineres pubertetsstart av at testikkelvolumet har nådd $4 \mathrm{~mL}$, og vurderes ved sammenlignende palpasjon av testikkel med et Praderorkidometer (se appendiks 1 for metodene for å vurdere pubertet klinisk).

Pubertetsreferansen tar utgangspunkt i såkalte Tanner-stadier, som ble publisert av pediateren James Tanner på 6o-tallet $(\underline{6}, 7.7)$. Tanner-stadier brukes for å definere grad av pubertetsmodning, der kjønnsbehåring (begge kjønn) og brystutvikling (jenter) vurderes på en skala fra 1 til 5. Fordi alle jenter/kvinner ikke når stadium $\mathrm{B}_{5} / \mathrm{P}_{5}$, og gutter ikke nødvendigvis når stadium $\mathrm{P}_{5}$, er disse stadiene utelatt fra referansen. I den reviderte referansen er det også presentert nye prosentiler for første menstruasjon (menarke).

I Vekststudien i Bergen 2 kartla vi pubertetsutviklingen også ved bruk av ultralyd. Dette er en ny metode for å karakterisere utviklingsstadiene av brystvekst og volumet av testiklene. Ultralyd er ikke brukt i vanlig klinisk praksis og er derfor ikke med i de oppdaterte referansene.

Referansene for pubesbehåringen, brystutviklingen, menarke og testikkelvolum vises i likhet med tidligere som prosentiler på horisontale linjer langs x-aksen til vekstkurvene (se appendiks 2 og appendiks 3).3-, 10-, 25-, 50-, 75- og 97-aldersprosentil er markert med tall. 3prosentilen indikerer ved hvilken alder $3 \%$ av henholdsvis jenter og gutter har nådd et gitt stadium.

\section{Kliniske konsekvenser}

Medianalder for starten av puberteten hos norske jenter er nå 10,4 år, og er dermed seks måneder lavere enn i den tidligere benyttede danske referansen. Pubertetsstarten hos norske gutter er i dag 11,7 år, noe som korresponderer med den danske referansen (11,8 år). Medianalder for menarke er i den norske referansen 12,7 år. Dette tilsvarer en forskjell på 8,7 måneder fra de danske referansene, og er fem måneder tidligere enn i Vekststudien $\mathrm{i}$ Bergen 1(2003-2006). Vi har tidligere anbefalt at grensene for tidlig og sein pubertet opprettholdes i tråd med dagens anbefaling i pediatriveilederen $(\underline{8}$, .9.). Tidlig og sein pubertetsutvikling defineres av aldrene som tilsvarer \pm 2 standardavvik fra gjennomsnittet eller medianen. Det anbefales at jenter under 8 år og gutter under 9 år med tegn på pubertetsutvikling utredes med tanke på underliggende årsak til for tidlig pubertet og eventuelt behandling. I tråd med de nye referansene bør jentene ha startet pubertet innen de er 13 år og guttene innen de er 14,5 år. 
Pubertetsreferansene gir et bilde av hvordan jenter og gutter utvikler seg i Norge nå. Referansene baserer seg på data fra friske barn (703 jenter og 514 gutter) i alderen 6-16 år fra et tilfeldig utvalg av syv skoler i Bergen kommune. Studiepopulasjonen har lignende prevalens av overvekt og fedme som i den øvrige norske barnebefolkningen, og forholdet mellom barn og ungdom med norsk og ikke-norsk opprinnelse er sammenlignbar med hele Norge (16,2 \% jenter og 22,6\% gutter hadde ikke-norsk opphav). Vi mener derfor at utvalget kan representere den øvrige norske befolkningen i den aktuelle aldersgruppen, og at referansene er til bruk for barn og ungdom som bor i Norge. Referansene vil indikere om en pubertetsmarkør har oppstått tidig, normalt eller sent, men gir ingen informasjon om helse eller sykdom. En grundig klinisk undersøkelse og anamnese bør være første skritt ved et klinisk bilde som kan indikere for tidlig eller for sein pubertet.

\section{LITTERATUR}

1. Júlíusson PB, Roelants M, Eide GE et al. Vekstkurver for norske barn. Tidsskr Nor Legeforen 20o9; 129: 281-6. [PubMed][CrossRef]

2. Juul A, Teilmann G, Scheike T et al. Pubertal development in Danish children: comparison of recent European and US data. Int J Androl 2006; 29: 247-55, discussion 286-90. [PubMed][CrossRef]

3. Aksglaede L, Sørensen K, Petersen JH et al. Recent decline in age at breast development: the Copenhagen Puberty Study. Pediatrics 2009; 123: e932-9. [PubMed][CrossRef]

4. Oehme NHB, Roelants M, Saervold Bruserud I et al. Reference data for testicular volume measured with ultrasound and pubic hair in Norwegian boys are comparable with Northern European populations. Acta Paediatr 2020; 109: 1612-9. [PubMed][CrossRef]

5. Bruserud IS, Roelants M, Oehme NHB et al. References for ultrasound staging of breast maturation, Tanner breast staging, pubic hair and menarche in Norwegian girls. J Clin Endocrinol Metab 2020; 105: 1599-607. [PubMed][CrossRef]

6. Marshall WA, Tanner JM. Variations in pattern of pubertal changes in girls. Arch Dis Child 1969; 44: 291-303. [PubMed][CrossRef]

7. Marshall WA, Tanner JM. Variations in the pattern of pubertal changes in boys. Arch Dis Child 1970; 45: 13-23. [PubMed][CrossRef]

8. Oehme N, Bruserud IS, Madsen A et al. Starter puberteten tidligere enn før? Tidsskr Nor Legeforen 2020; 140. doi: 10.4045/tidsskr.20.0043. [PubMed][CrossRef]

9. Norsk barnelegeforening. Pediatriveileder. 2.4: Normal pubertet. https://www.helsebiblioteket.no/pediatriveiledere?

menuitemkeylev1 $=5962 \&$ menuitemkeylev2 $=5964 \&$ key $=144406$ Lest 6.4.2021.

Publisert: 21. april 2021. Tidsskr Nor Legeforen. DOI: 10.4045/tidsskr.21.0210

Mottatt 17.3.2021, godkjent 6.4.2021.

(C) Tidsskrift for Den norske legeforening 2023. Lastet ned fra tidsskriftet.no 26. april 2023. 